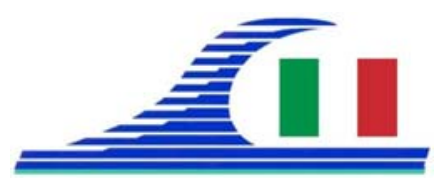

Conférence Méditerranéenne Côtière et Maritime

EDITION 3, FERRARA, ITALIA (2015)

Coastal and Maritime Mediterranean Conference

Disponible en ligne - http://www.paralia.fr - Available online

\title{
Costal flood risk in Emilia-Romagna (Italy): the sea storm of February 2015
}

\author{
Luisa PERINI ${ }^{1}$, Lorenzo CALABRESE ${ }^{1}$, Samantha LORITO ${ }^{1}$, Paolo LUCIANI ${ }^{1}$ \\ 1. Servizio Geologico,Sismico e dei Suoli, Regione Emilia-Romagna, \\ via Della Fiera, 840127 Bologna, Italy. \\ lperini@regione.emilia-romagna.it
}

\begin{abstract}
:
The Emilia-Romagna Region has developed an integrated system for the management of sea-storm risk based on agreements between different public authorities and industry, on cartographic products and IT services. A sea-storm occurred on 6 February 2015 offered the opportunity to test the part of the operative chain responsible for data collection, monitoring and analysis of the impacts, which belongs to the regional geological service (SGSS) and to improve the knowledge about the phenomenon.

The forecast models have predicted two days before the severity of the event and the Civil Protection issued a prompt warning. It was activated immediately the observation procedure and the data collection, including remote sensing information (photos and movies), those were invaluable for the analysis of the impacts and for the creation of dedicated maps. Besides, it was possible to check the flood hazard maps of the Directive 2007/60, confirming the strength of the adopted model.
\end{abstract}

Keywords: Coastal risk, Sea storm, Remote sensing information, Early warning, Hazard mapping, ICZM.

\section{Introduction}

Severe sea-storms have strongly affected the European coasts during last few decades, for this reason the European Commission added sea-flooding among the processes considered by the Directive EU 2007/60, so far excluded from the previous laws.

The Emilia-Romagna coastal plain has morphological features that make it highly vulnerable, e.g. extensive areas below sea level, most of them reclaimed and populated, discontinuity of coastal dunes, the subsidence and beach erosion due to input of sediment by rivers. The exposure of these areas has been amplified by the uncontrollable urbanization, which, has increased by $400 \%$ over the last sixty years.

Aware of this weakness the Emilia-Romagna government has long dealt with the defence of the coast, implementing an ICZM plan and developing studies and tools and cartography for the sea storms prevention (PERINI \& CALABRESE, 2010). On the issue of sea-flood risk mapping, a 2D map of the northern Adriatic coast was published by BONDESAN et al. (1995) whereas vulnerability maps along profiles were processed (ARMAROLI et al., 2009). The maps processed under EU 2007/60 directive (PERINI 
Côtes méditerranéennes menacées :

Risques et défis dans le contexte du changement climatique

et al., 2015), are extremely important because they impose new rules for future land use planning, and, therefore, they must be adequately tested. The maps were calibrated through a wide collection of data on historical storms (PERINI et al., 2011) and there were the necessity of testing the maps with a new event next to the scenarios and adequately monitored. The sea storms occurred on 6 February 2015 that caused urban flooding, loss of tourism infrastructures and breaking of coastal works, provided this opportunity as well as testing the entire coastal risk management system. This storm was one of the most catastrophic events in living memory for the combination of wave and tide among the highest ever recorded. A low barometric pressure that brought heavy rainfall causing serious hydraulic crisis in the coastal sector also characterized the storm.

\section{Materials and methods}

Large amounts of data were acquired by SGSS, other public authorities and privates and were stored and processed within in_Storm (REGIONE EMILIA-ROMAGNA, Website).

Wave and tide information were useful for the sea state characterization and analysis of the return period and they were collected by different parties (Arpa-SIMC, ISPRA, Ferrara Province, ENI and Hera) and examined by SGSS. The tide gauges in Porto Corsini and Porto Garibaldi recorded peaks respectively of 1.21 and $1.30 \mathrm{~m}$ above sea level (values attributable to a return period greater than 100 years). Higher tides were contextual to waves exceeding $4 \mathrm{~m}$.

The wave peak recorded in the early hours of February 6 was $4.66 \mathrm{~m}$, the highest ever recorded by the Cesenatico wave buoy, which corresponds to a return period of about ten years. Webcam images, aerial photos, panoramic photos and field surveys, were examined to evaluate and map the storm impacts. The webcam images, recorded starting from 4 February, offered an interesting view of the evolution of the beach during the storm. Firefighters made immediately a survey by helicopter over the flooded coastal areas (Fig. 1), while during the days after the event two other flights were carried out covering the whole regional coast.

\section{Results}

The large amount of data allowed to make important evaluations of the damage and improved the knowledge of sea flooding, highlighting the importance of images and remote sensing tools. The webcams, for example, were very useful for observing the complex coastline dynamic and how and where the collapse of the temporary defences occurred, e.g. in the artificial dune morphological changes took place gradually over the course of the storm, and only after several hours induced the failure, as well as confirming the importance of the factor "duration" for the prediction of damage as numerically predicted by HARLEY and CIAVOLA (2013). 
Maps of the impacts were produced in a short time thanks to georeferencing and processing of all integrated data; these maps reproduce: the line of maximum ingression of the sea, the most intense hydro-morphological processes as outflow channels, overwash deposits and erosion hotspots, damage to infrastructure and coastal defences. These processes resulted in a serious loss of sand from the beach system: the overwash caused a strong landward transport of sediments, e.g. at Lido di Savio where it reached $50 \mathrm{~cm}$ thick, whereas outflow channels on the beach, locally connected to the deep inlets between breakwaters, increased the moving of sand towards the outer beach.

Photographic images locally allowed to integrate mapping and estimate the maximum water level reached in the urban area and the amount of sand deposited in the backshore. The quantification and classification of the impacts on the territory, are summarized in the table below.

Table 1 Summary of impact on the coast.

\begin{tabular}{ll}
\hline Flooded areas & $18.5 \mathrm{~km}^{2} ; 31 \mathrm{~km}^{2}$ P2 areas of Flood Directive Maps. \\
Overflowing of mouth channel & 9 \\
Overwash & 40 \\
Punctual passage/corridor & 5 \\
Linear passage & $15 \mathrm{~km}$ cumulated \\
Outflow channel & 19 \\
Filtration & 13 (correspond to emergency of water table or siphoning) \\
Erosion hotspot & 33 \\
Dune erosion & 10 tracts \\
Damage to touristic infrastructure & 27 \\
Damage to coastal defence & 7 \\
\hline
\end{tabular}

The event also provided an opportunity to verify the consistency of the maps of the Directive EU 2007/60. The characteristics of the storm in fact make it suitable for a comparison with the scenarios simulated by the maps; in particular, the meteo-marine values make the event similar to the "P2" scenario, related to infrequent storms with return period of 100 years.

A careful analysis highlighted that a good conformity between the observed and simulated flooded areas exist and locally they fit perfectly.

The total flooded areas are smaller then simulated ones because temporary defences, such as those protecting Goro, not considered in the Flood Directive Maps, have adequately protected areas behind. The observations of water level in urban areas gave a new key information, in fact this parameter, not considered in the simulations, will be a reference datum for the future update of the Flood Directive Maps, planned for 2018. 
Côtes méditerranéennes menacées :

Risques et défis dans le contexte du changement climatique

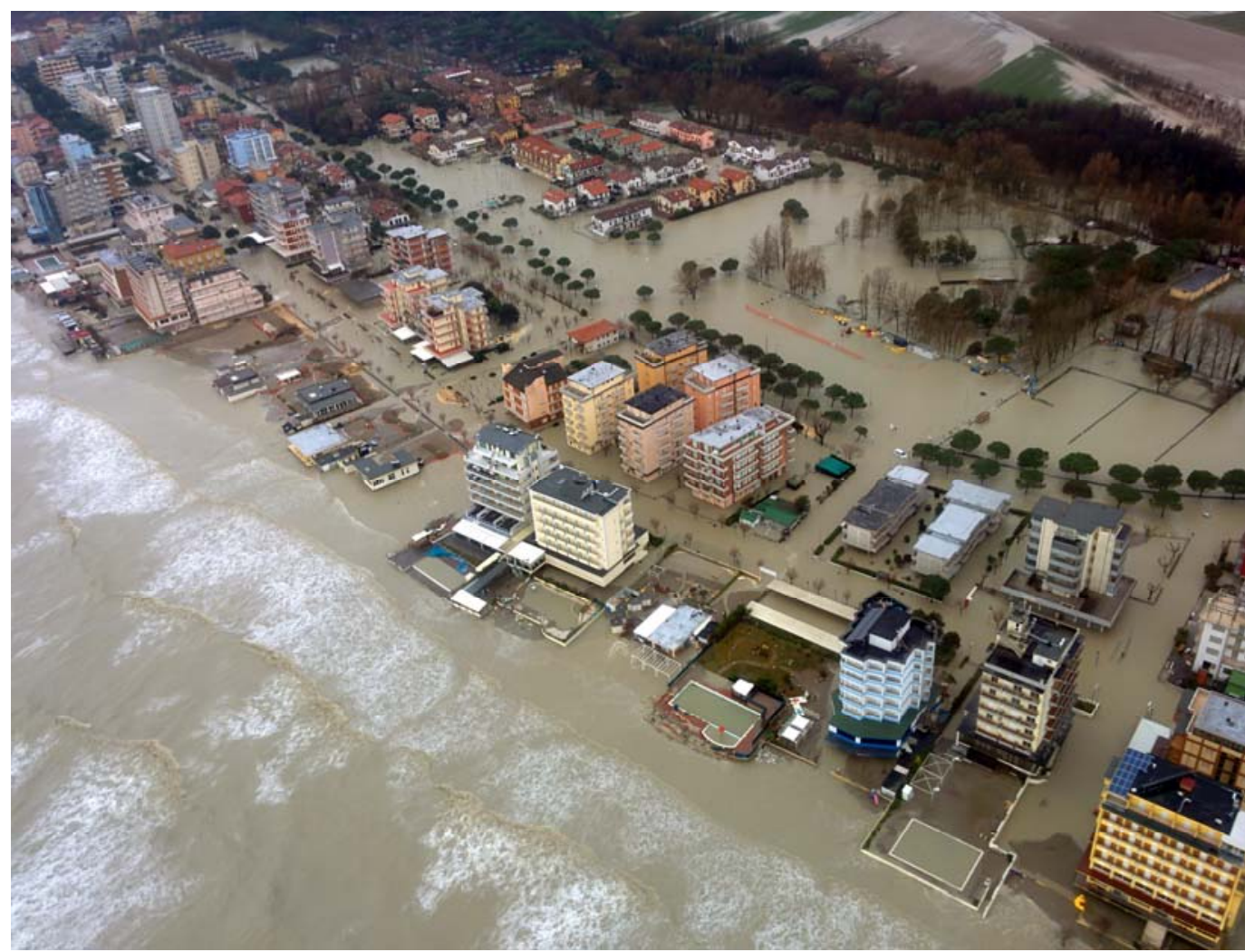

Figure 1. Sea-flooding at Lido Di Savio (Ra).

\section{Conclusions}

The sea storm that occurred on the 6 February 2015 was used to check the current procedure for alerting and studying the nature of impacts and to verify several tools and maps developed in Emilia-Romagna. The forecasting system, which is running an innovative Early Warning Tool (HARLEY et al., 2012), correctly predicted the big storm: the alert of Civil Protection was promptly sent out and the monitoring of phenomenon and impacts was organized. In particular, meteo-marine data from different sources, made available thanks to agreement among parties, made possible the physical characterization of the storm. Likewise the immediate aerial survey has greatly supported the damage analysis and assessment. The observed flooding also provided an adequate comparison for the scenarios of Flood Directive Maps, confirming their consistency.

The event also highlighted the opportunities for a better risk assessment system, as example by using new remote sensing technology, i.e. special web-cams equipped with infrared technology or radar monitoring of the state of the sea. The acquisition of aerial images or high-resolution satellite data should be assessed and planned in advance on the event to achieve even more appreciable results. Other useful improvements will be the best dimensioning of temporary defence as artificial dune and the definition of solutions to limit the loss of sediment. 
Mediterranean coasts at threat:

Hazards and challenges in the context of climate variability

\section{References}

ARMAROLI C., CIAVOLAP., MASINAM., PERINI L. (2009). Run-up computation behind emerged breakwaters for marine storm risk assessment. Journal of Coastal Research, Vol. SI 56, pp 1612-1616.

BONDESAN M., CASTIGLIONI G.B., ELMI C., GABBIANELLI G., MAROCCO R., PIRAZZOLI P.A., TOMASIN A. (1995). Coastal areas at risk from storm surges and sea level rise in northeastern Italy. Journal of Coastal Research, Vol. 11, pp 1374-1379. HARLEY M., CIAVOLA P. (2013). Managing local coastal inundation risk using realtime forecasts and artificial dune placements. Coastal Engineering, Vol. 77, pp 77-90. http://dx.doi.org/10.1016/j.coastaleng.2013.02.006

HARLEY M., VALENTINI A., ARMAROLI C., CIAVOLA P., PERINI L., CALABRESE L., MARUCCI F. (2012). An early warning system for the on-line prediction of coastal storm risk on the Italian coastline. Coastal Engineering Proceedings, Vol. 1(33), management.77. http://dx.doi.org/10.9753/icce.v33.management.77 PERINI L. E CALABRESE L. (a cura di) (2010). Il sistema mare-costa dell'EmiliaRomagna; Bologna: Pendragon. Monografie.

PERINI L., CALABRESE L., DESERTI M., VALENTINI A., CIAVOLA P., ARMAROLI C. (2011). Le Mareggiate E Gli Impatti Sulla Costa in Emilia-Romagna, 1946-2010. Bologna: I Quaderni di ARPA - Regione Emilia Romagna.

PERINI L., CALABRESE L., SALERNO G., CIAVOLA P., ARMAROL C. (2015). Evaluation of coastal vulnerability to flooding: comparison of two different methodologies adopted by the Emilia-Romagna Region (Italy), Nat. Hazards Earth Syst. Sci. Discuss., Vol. 3, pp 4315-4352. http://dx.doi.org/10.5194/nhessd-3-4315-2015

REGIONE EMILIA-ROMAGNA (Website). Portale ER Ambiente. URL : http://ambiente.regione.emilia-romagna.it/geologia/temi/costa/in_storm-il-sistema-informativo-per-la-gestione-delle-mareggiate 
Côtes méditerranéennes menacées :

Risques et défis dans le contexte du changement climatique 